\title{
ATRA increases iodine uptake and inhibits the proliferation and invasiveness of human anaplastic thyroid carcinoma SW1736 cells: Involvement of $\boldsymbol{\beta}$-catenin phosphorylation inhibition
}

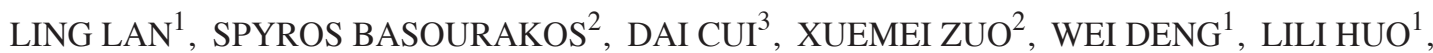 \\ HAILING CHEN $^{1}$, GUOYING ZHANG ${ }^{1}$, LILI DENG ${ }^{1}$, BINGYIN SHI ${ }^{4}$ and YONG LUO ${ }^{2,5}$ \\ ${ }^{1}$ Department of Endocrinology, Beijing Jishuitan Hospital, Beijing 100035, P.R. China; ${ }^{2}$ Department of Genitourinary, \\ Cancer Medicine, MD Anderson Cancer Center, University of Texas, Houston, TX 77030, USA; \\ ${ }^{3}$ Department of Endocrinology, First Affiliated Hospital of Nanjing Medical University, Nanjing, Jiangsu 210029; \\ ${ }^{4}$ Department of Endocrinology, First Affiliated Hospital of Medical College of Xi'an Jiaotong University, Xi'an, \\ Shaanxi 710061; ${ }^{5}$ Department of Urology, Beijing Anzhen Hospital, Capital Medical University, Beijing 100029, P.R. China
}

Received April 1, 2016; Accepted August 10, 2017

DOI: $10.3892 / 01.2017 .7225$

\begin{abstract}
All-trans-retinoic acid (ATRA) can enhance iodine uptake capability of thyroid tumors, but the mechanisms remain poorly understood. The aim of the present study was to investigate the effects of ATRA on isotope susceptibility, proliferation and invasion of anaplastic thyroid carcinoma (ATC) and potential mechanisms. SW1736 cells were treated with $1 \mu \mathrm{mol} / 1$ ATRA or $1 \%$ ethanol for 5 days. A cell line stably expressing $\beta$-catenin-shRNA was established. An iodine uptake assay was performed using ${ }^{125} \mathrm{I}$. Proliferation and invasiveness were tested using MTT and Transwell assays, respectively. Western blotting was used to assess the expression of $\beta$-catenin, glycogen synthase

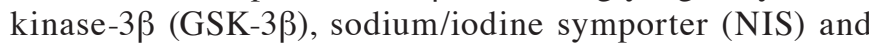
proteins involved in epithelial-mesenchymal transition. Cells pretreated with ATRA were injected subcutaneously into SCID mice. Mice were intraperitoneally injected with ${ }^{131} \mathrm{I}$ once on the first day of treatment, and tumor growth was then assessed. After 35 days of ${ }^{131}$ I treatment, ATRA-pretreated tumor volume and weight were decreased compared with the ${ }^{131} \mathrm{I}$ alone group $\left(163.32 \pm 19.57\right.$ vs. $332.06 \pm 21.37 \mathrm{~mm}^{3}$; $0.35 \pm 0.14$ vs. $0.67 \pm 0.23 \mathrm{~g}$, both $\mathrm{P}<0.05)$. Similar results were observed in the $\beta$-catenin shRNA-pretreated tumors. ATRA
\end{abstract}

Correspondence to: Dr Ling Lan, Department of Endocrinology, Beijing Jishuitan Hospital, Xinjiekou Dongjie, Xicheng, Beijing 100035, P.R. China

E-mail: lanjingling0627@hotmail.com

Dr Yong Luo, Department of Urology, Beijing Anzhen Hospital, Capital Medical University, 2 Anzhen Road, Chaoyang, Beijing 100029, P.R. China

E-mail: luoyongdoctor@163.com

Key words: anaplastic thyroid carcinoma, all-trans-retinoic acid, sodium/iodine symporter, isotope susceptibility also increased the uptake of iodine by SW1736 cells $(\mathrm{P}<0.01)$, and similar results were observed in $\beta$-catenin shRNA cells. ATRA treatment decreased the cell proliferation and invasion compared with control cells (all $\mathrm{P}<0.05)$, similar to $\beta$-catenin shRNA. ATRA treatment decreased the expression of phosphorylated ( $\mathrm{p}-) \beta$-catenin, $\mathrm{p}-\mathrm{GSK}-3 \beta$, vimentin, and fibronectin, and increased the expression of NIS and E-cadherin, compared with the control. ATRA increased the iodine uptake and inhibited the proliferation and invasion of SW1736 cells, involving $\beta$-catenin phosphorylation. In conclusion, ATRA could be used to improve the isotope sensitivity of ATC.

\section{Introduction}

Thyroid cancer is an endocrine malignancy with a high morbidity rate (1). Anaplastic thyroid cancer (ATC) is the least common, but most lethal, form of thyroid cancer. It accounts for $1.3-9.8 \%$ of thyroid in worldwide, with a 1-year survival rate of $20 \%$ and a disease-specific mortality rate of nearly $100 \%$ (2). ATC has an annual incidence of between 1 and 2 cases/million people, with a female to male ratio of 3:2 (3). Although the majority of well-differentiated thyroid tumors are effectively treated by isotope therapy, relapse and poorly differentiated thyroid cancer, such as anaplastic and medullary thyroid cancers, show tolerance to isotope treatment (1). Therefore, finding new ways to improve the effectiveness of isotope-based therapies for this type of cancer is important.

All-trans-retinoic acid (ATRA) is naturally produced by humans. ATRA is a natural derivative of vitamin A. ATRA exerts its functions by triggering G1 phase arrest, affecting DNA synthesis and enhancing immune cell killing efficiency $(4,5)$. ATRA has been shown to decrease the proliferation and invasiveness of different types of cancer cells, including pancreatic cancer (6), leukemia (7), breast cancer (8) and thyroid cancer cells (9). Particularly, ATRA can significantly enhance the iodine uptake capability of thyroid tumors and other cancers $(4,5,10,11)$. However, the mechanisms of the 
enhancement of iodine uptake in thyroid cancer induced by ATRA remain poorly understood.

The sodium/iodine symporter (NIS) is a transmembrane protein responsible for the transport of iodine into the thyroid follicular cells, which is a crucial step for the synthesis of hormones, including $\mathrm{T}_{3}$ and $\mathrm{T}_{4}(12)$. This property of NIS to concentrate iodine ions within thyroid cells constitutes the basis for thyroid scintigraphy and iodine isotope treatment of hyperthyroidism and thyroid cancer (12). Loss of thyroid-specific functions in poorly differentiated thyroid cancer leads to the lack of efficacy of isotope therapy in these cancers (13). Identifying methods to restore the NIS function may be one way to improve the treatment efficacy in anaplastic thyroid carcinoma.

Previous studies have suggested that the transcription activity of $\beta$-catenin is closely associated with the transcription of genes involved in thyroid cell growth and differentiation, as well as NIS gene transcription and translation in thyroid cancer $(14,15)$. Therefore, it may be hypothesized that the transcription activity of $\beta$-catenin can directly affect the isotope sensitivity of thyroid cancer cells. The aim of the present study was to investigate whether the transcription activity of $\beta$-catenin plays a role in ATRA-mediated iodine uptake in thyroid cancer.

\section{Materials and methods}

Cells. Undifferentiated human anaplastic thyroid carcinoma SW1736 cells were provided by Professor Michael Derwahl (Institute of Endocrinology, Hedwig Hospital, Humboldt University, Berlin, Germany); this cell line has a tolerance to isotope treatment (16). The cells were maintained in DMEM (Gibco; Thermo Fisher Scientific, Inc., Waltham, MA, USA) with $10 \%$ fetal bovine serum (FBS) (Gibco; Thermo Fisher Scientific, Inc.) in an incubator at $37^{\circ} \mathrm{C}$ with $5 \% \mathrm{CO}_{2}$.

ATRA (Sigma-Aldrich; Merck KGaA, Darmstadt, Germany) was dissolved in ethanol to $10 \mu \mathrm{mol} / \mathrm{l}$ as stock solution and stored in the dark. SW1736 cells were seeded at a density of $5 \times 10^{4}$ cells/well for $48 \mathrm{~h}$, followed by ATRA treatment $(1 \mu \mathrm{mol} / 1)$ for 5 days. The negative control cells were treated with $1 \%$ ethanol. All cells were kept at $37^{\circ} \mathrm{C}$ in the dark using aluminum foil. SW1736 cells stably transfected with $\beta$-catenin shRNA were used as positive controls.

$\beta$-catenin RNA interference and stable cell lines. The recombinant plasmid pSUPER- $\beta$-catenin-shRNA was previously constructed (17). It was transfected into SW1736 cells using Lipofectamine 2000 (Thermo Fisher Scientific, Inc.). SW1736 cells transfected with pSUPER- $\beta$-catenin-shRNA were screened by $400 \mu \mathrm{g} / \mathrm{ml}$ puromycin for 4 weeks to select positive clones. Finally, cells were screened and cultured in medium with $200 \mu \mathrm{g} / \mathrm{ml}$ of puromycin to establish the stable transfected cell line.

Proliferation assay. SW1736 cells treated with $1 \mu \mathrm{mol} / 1$ of ATRA or $1 \%$ ethanol for 5 days were seeded onto a 96-well culture plate. Each well was loaded with $180 \mu \mathrm{l}$ of cell suspension containing $1 \times 10^{4}$ cells. After 24, 48 and $72 \mathrm{~h}$, the supernatant was discarded and cells were treated with $150 \mu \mathrm{l}$ DMEM and $50 \mu \mathrm{l}$ MTT solution $(2.5 \mathrm{mg} / \mathrm{ml}$; Sigma-Aldrich;
Merck KGaA). The MTT solution was discarded following $4 \mathrm{~h}$ of treatment, and the cells were mixed with $150 \mu$ l dimethyl sulfoxide at low-speed vortex for $10 \mathrm{~min}$. The absorbance of each well was measured at $570 \mathrm{~nm}$ using DNM-9602 ELISA spectrometer (Perlong Medical Equipment Co., Ltd., Beijing, China).

In vitro invasion assay. Transwell chambers (Merck KGaA) coated with Matrigel (Sigma-Aldrich; Merck KGaA) were placed into 6-well plates and air-dried under a sterile laminar flux hood. DMEM medium (700 $\mu \mathrm{l})$ containing 10\% FBS was added to the lower chamber. Cell suspension $(300 \mu \mathrm{l})$ containing $5.0 \times 10^{4} \mathrm{SW} 1736$ cells treated with $1 \mu \mathrm{mol} / 1$ ATRA or $1 \%$ ethanol, but without FBS, for 5 days was added to the upper chamber. After 24, 48 and 72 h, the Transwell chambers were washed with phosphate-buffered saline (PBS). The upper microporous membrane was cleaned with cotton swab. Invading cells attached to the lower microporous membrane were fixed with $2 \%$ paraformaldehyde for $30 \mathrm{~min}$ and stained with hematoxylin. Cell counting was performed by two independent investigators blind to grouping.

In vitro iodine uptake assay. The in vitro iodine uptake assay was performed as previously described (18). Briefly, SW1736 cells treated with $1 \mu \mathrm{mol} / \mathrm{l}$ ATRA or $1 \%$ ethanol for 5 days were seeded onto 6 -well plates $\left(5.0 \times 10^{4}\right.$ cells/well). After the cells had attached to the bottom surface, the supernatant was discarded. Cells were washed with Hank's balanced salt solution (HBSS) and incubated with $3.7 \mathrm{kBq}$ of ${ }^{125} \mathrm{I}$ (Thermo Fisher Scientific, Inc.) for $20 \mathrm{~min}$ followed by three washes with ice-cold HBSS. Cells were then incubated with $1 \mathrm{ml}$ of ethanol for $20 \mathrm{~min}$. The ethanol solution was collected into test tubes and the radioactivity per minute was measured using a WIZARD $\gamma$ counter (Perkin-Elmer Life Sciences, Waltham, MA, USA).

Western blot analysis. SW1736 cells treated with $1 \mu \mathrm{mol} / 1$ ATRA or $1 \%$ ethanol for 5 days were lysed with $1 \%$ NP-40 lysis buffer (Sigma-Aldrich; Merck $\mathrm{KGaA}$ ) at $4^{\circ} \mathrm{C}$ for $30 \mathrm{~min}$. Total proteins were collected after centrifugation at 25,000 x g for $10 \mathrm{~min}$ at $4^{\circ} \mathrm{C}$. Proteins were quantified using Coomassie brilliant blue G-250. Samples of 20-50 $\mu \mathrm{g}$ per well were separated on $8-12 \%$ SDS-PAGE and transferred to nitrocellulose membranes. The membranes were blocked with $5 \%$ non-fat milk for $2 \mathrm{~h}$ followed by incubation with primary antibodies against $\beta$-catenin (dilution: 1:4,000; cat. no. ab16051; Abcam, Cambridge, MA, USA), phosphorylated (p-) $\beta$-catenin Ser45 (dilution, 1:1,000; cat. no. PA5-17685; Invitrogen; thermo Fisher Scientific, Inc.), p- $\beta$-catenin Y654 (dilution, 1:1,000; cat. no. ab59430, Abcam), glycogen synthase kinase-3 $\beta$ (GSK-3 $\beta$ ) (dilution, 1:10,000; cat. no. ab75814, Abcam), p-GSK-3 $\beta$ Ser9 (dilution, 1:10,000; cat. no. ab75814; Abcam), E-cadherin (dilution, 1:1,000; cat. no. sc-7870; Santa Cruz Biotechnology, Inc., Dallas, TX, USA), cytokeratin 18 (CK18) (dilution: 1:1,000; cat. no. sc-28264; Santa Cruz Biotechnology, Inc.), vimentin (dilution: 1:1,000; cat. no. sc-5565; Santa Cruz Biotechnology, Inc.), urokinase-type plasminogen activator (uPA) (dilution: 1:1,000; cat. no. sc-14019; Santa Cruz Biotechnology, Inc.) and its receptor uPAR (dilution: 1:1,000; cat. no. sc-10815; Santa Cruz Biotechnology, Inc.), and fibronectin (dilution, 1:1,000; 
cat. no. sc-9068; Santa Cruz Biotechnology, Inc.) at $4^{\circ} \mathrm{C}$ overnight. The next day, the membranes were extensively washed with Tris-buffered saline and incubated with goat anti-rabbit secondary antibody (dilution: 1:30,000; cat. no. A9919; Sigma-Aldrich; Merck KGaA, Darmstadt, Germany) for $2 \mathrm{~h}$ at $4^{\circ} \mathrm{C}$. The bands were visualized by electrochemiluminescence (Pierce; Thermo Fisher Scientific, Inc.). Densitometry images were analyzed using ImageJ software (Rawak Software, Inc., the Tomancak Laboratory, Dresden, Germany).

Heterotopic xenograft mouse model. SW1736 cells $\left(2 \times 10^{6}\right)$ were treated with $1 \mu \mathrm{mol} / 1$ ATRA or $1 \%$ ethanol for 5 days, and SW1736 cells stably transfected with $\beta$-catenin shRNA were suspended in $200 \mu \mathrm{l}$ of culture medium and implanted subcutaneously into the left forelimb of 4-6-week-old male SCID mice (22-25 g body weight). Intervention was applied after the subcutaneous tumor size reached $50 \mathrm{~mm}^{3}$. The experimental mice (alcohol, $\beta$-catenin shRNA and ATRA groups) were intraperitoneal injected with $37 \mathrm{MBq}$ of ${ }^{131} \mathrm{I}$ (Thermo Fisher Scientific, Inc.) once on the first day of treatment. The control mice (ATRA and alcohol groups) were intraperitoneally injected with $0.1 \mathrm{ml}$ of normal saline (NS) instead (ATRA+NS and Alcohol+NS). There were 10 mice in each group (supplied by Beijing Huafukang Biotechnology Co., Ltd., Beijing, China). The ${ }^{131}$ I intervention was commenced on the first day of the experiment. Subcutaneous tumor size was measured every 5 days using a caliper (volume=long diameter $\mathrm{x}$ short diameter $\left.{ }^{2}+2\right)$. Mice were sacrificed by $\mathrm{CO}_{2}$ inhalation after 35 days of observation. Tumors were collected and weighed. All procedures and animal experiments were approved by the Animal Care and Use Committee of Beijing Jishuitan Hospital (Beijing, China).

Statistical analysis. All statistical analyses were conducted using SPSS 13.0 (SPSS Inc., Chicago, IL, USA). Data are expressed as the mean \pm standard deviation (SD) from three independent experiments performed in triplicate. Statistical significance was evaluated by one-way analysis of variance, with the least significant difference test for post-hoc analysis. $\mathrm{P}<0.05$ was considered to indicate a statistically significant difference.

\section{Results}

ATRA pretreatment improved ${ }^{131}$ I sensitivity and inhibited tumor growth in the heterotopic xenograft mouse model. After 35 days of ${ }^{131}$ I treatment, ATRA-pretreated tumor volume and weight were decreased compared with the alcohol $+{ }^{131} \mathrm{I}$ group $\left(163.32 \pm 19.57\right.$ vs. $332.06 \pm 21.37 \mathrm{~mm}^{3} ; 0.35 \pm 0.14$ vs $0.67 \pm 0.23 \mathrm{~g}$; both $\mathrm{P}<0.05$ ) (Fig. 1). Similar results were observed in the $\beta$-catenin-shRNA $+{ }^{131} \mathrm{I}$ group $\left(116.3 \pm 14.4 \mathrm{~mm}^{3}\right.$ and $0.26 \pm 0.11 \mathrm{~g}$, both $\mathrm{P}<0.05$ vs. the alcohol $+{ }^{131} \mathrm{I}$ group). There were no differences in tumor volume and weight among the tumors treated with ATRA+NS, Alcohol+NS, and Alcohol $+{ }^{131} \mathrm{I}$ groups (all $\mathrm{P}>0.05$ ). Furthermore, there were no differences in the tumor volume and weight between the tumors treated with ATRA $+{ }^{131} \mathrm{I}$ and $\beta$-catenin-shRNA $+{ }^{131} \mathrm{I}$ (both $\mathrm{P}>0.05$ ) (Fig. 1).

Effect of ATRA on iodine uptake in the SW1736 cells. The iodine uptake assay revealed that ATRA increased the uptake

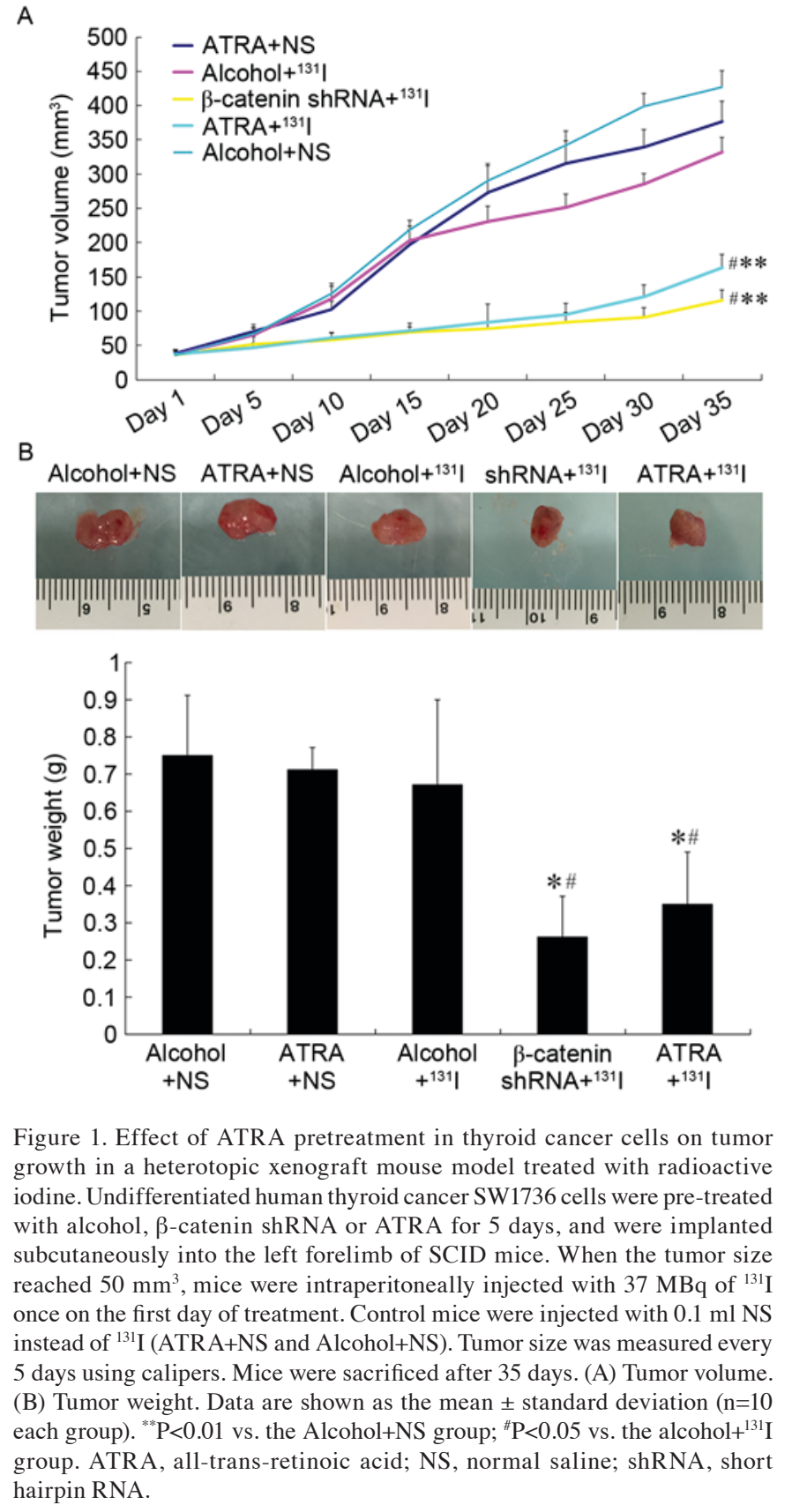

of iodine by SW1736 cells compared with the alcohol control group $\left(1.4 \pm 0.2\right.$ vs. $\left.0.4 \pm 0.2 \times 10^{3} / \mathrm{min} ; \mathrm{P}<0.01\right)$ (Fig. $\left.2 \mathrm{~A}\right)$. Similar results were observed in the $\beta$-catenin-shRNA cells compared with the no transfection group $\left(1.7 \pm 0.3\right.$ vs. $0.6 \pm 0.2 \times 10^{3} / \mathrm{min}$; $\mathrm{P}<0.01)$.

ATRA inhibited the invasion and proliferation of SW1736 cells. MTT and Transwell invasion assays indicated that ATRA treatment decreased the cell proliferation (Fig. 2B) and invasion (Fig. 2C) compared with untreated and alcohol control cells $(\mathrm{P}<0.05)$. $\beta$-catenin-shRNA cells showed results that were similar to the ATRA-treated cells.

Effects of ATRA on phosphorylation of $\beta$-catenin and GSK-3 $\beta$ in SW1736 cells. Western blot analysis revealed that ATRA 


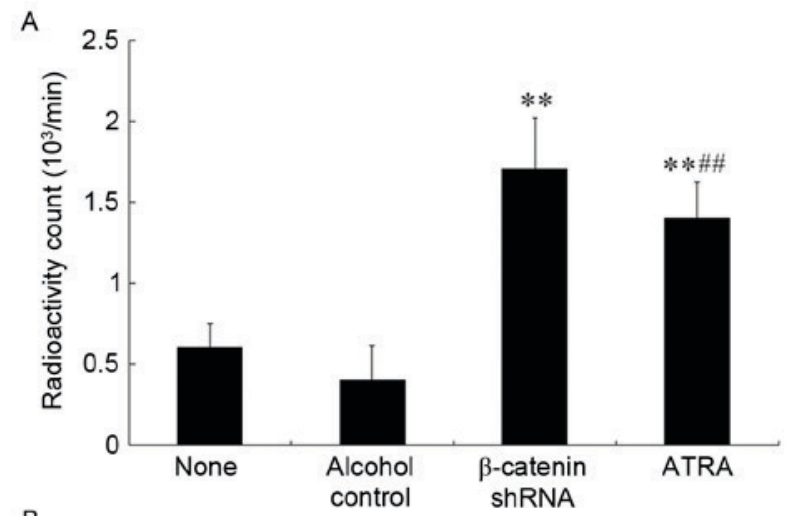

B

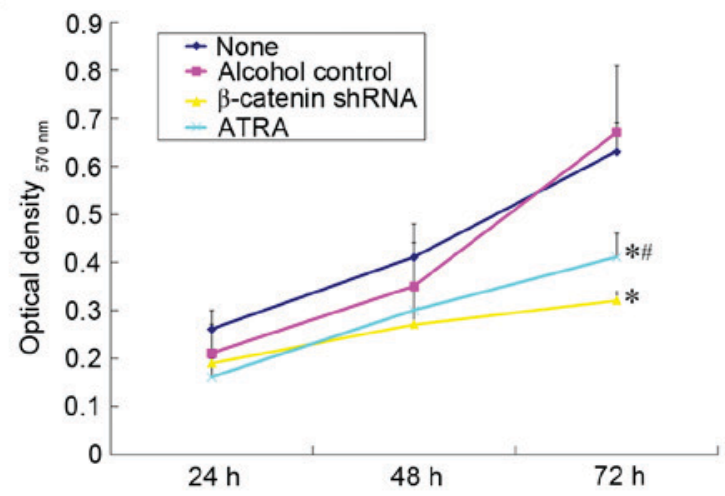

C
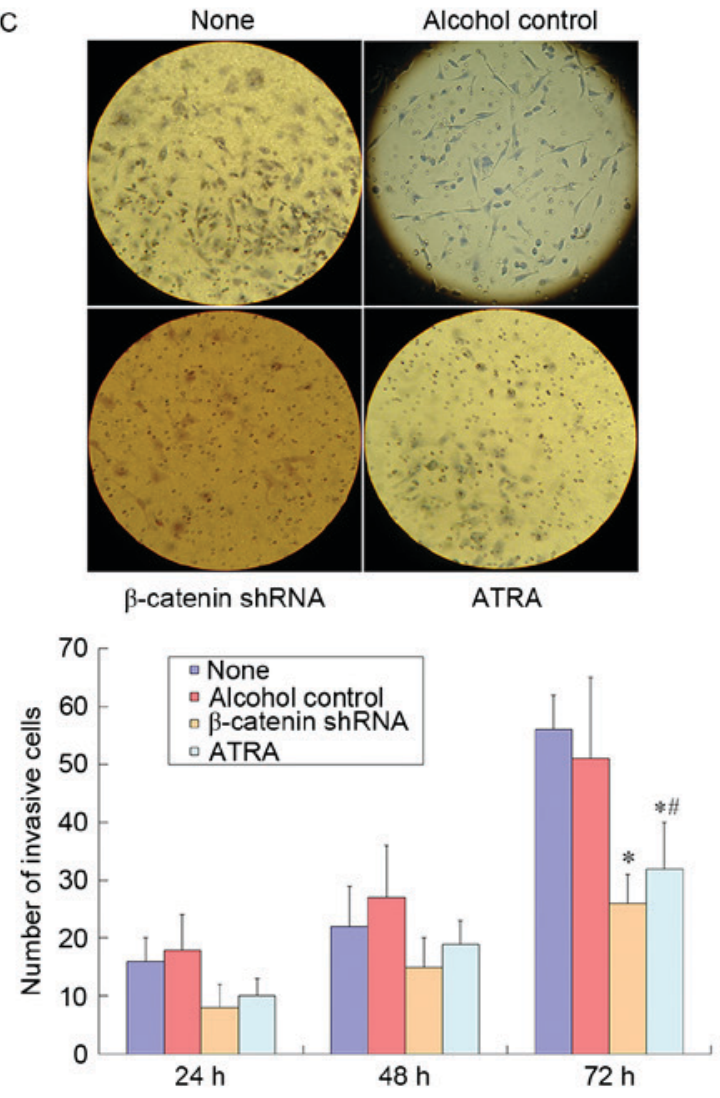

Figure 2. Effects of ATRA on iodine uptake, cell proliferation, and invasion of thyroid cancer SW1736 cells. SW1736 cells were treated with ATRA $1 \mu \mathrm{mol} / 1$ or $1 \%$ alcohol (as negative control) for 5 days. SW1736 cells stably transfected with $\beta$-catenin shRNA were considered as a positive control. (A) Iodine uptake. (B) Cell proliferation determined by MTT. (C) Cell invasion determined by Transwell assay. Data are shown as mean \pm standard deviation from three independent experiments performed in triplicate. ${ }^{*} \mathrm{P}<0.05,{ }^{* *} \mathrm{P}<0.01$ vs. None; ${ }^{\#} \mathrm{P}<0.05,{ }^{\# \#} \mathrm{P}<0.01$ vs. alcohol control. None, SW1736 cells without any treatment; ATRA, all-trans-retinoic acid; shRNA, short hairpin RNA. treatment decreased the expression of $\mathrm{t}-\beta$-catenin, $\mathrm{p}-\beta$-catenin Ser45, p- $\beta$-catenin Y654 and p-GSK-3 $\beta$, and increased the expression of t-GSK-3 $\beta$ compared with untreated and alcohol control cells (Fig. 3A). Similar results were observed in $\beta$-catenin-shRNA cells.

Western blot analysis also revealed that ATRA treatment increased the expression of NIS, E-cadherin and CK18, and decreased the expression of vimentin, uPA, uPAR and fibronectin compared with untreated and alcohol control cells (Fig. 3B). Similar results were observed in $\beta$-catenin-shRNA cells.

\section{Discussion}

Loss of thyroid-specific functions in undifferentiated thyroid cancers leads to a lack of efficacy of isotope therapy (1). ATRA may restore the NIS function to enhance iodine uptake capability in thyroid carcinoma $(4,5,10,11)$, but the exact mechanisms remain poorly understood. In the present study, ATRA treatment has been shown to increase iodine uptake by SW1736 cells, both in vitro and in vivo. This is consistent with the study by Muhlbauer et al (10), which revealed that ATRA could induce iodine accumulation in rats via the NIS. Similar results were also observed in medullary thyroid cancer stem cells and in mice (11).

The results of the present study indicate that the $\beta$-catenin pathway is involved in the process of ATRA-improved iodine uptake by SW1736 cells. ATRA inhibited $\beta$-catenin phosphorylation at Ser45 and GSK-3 $\beta$ phosphorylation at Ser9, which should consequently enhance GSK-3 $\beta$ hydrolytic activity and decrease $\beta$-catenin levels in the cytoplasm (19). In addition, phosphorylation of $\beta$-catenin at Y654 was decreased, which should inhibit the translocation of $\beta$-catenin to the nucleus (19), resulting in the restoration of NIS expression and the recovery of cellular iodine uptake capability and susceptibility to radioactive iodine therapy (19).

The restoration of NIS function should improve the sensitivity of undifferentiated thyroid cancers to isotope treatment. A recent study revealed that the $\mathrm{Wnt} / \beta$-catenin pathway is involved in thyroid function (14), and a previous study showed that $\beta$-catenin nuclear translocation suppresses NIS membrane localization in thyroid cancer cells (15). Other studies have shown that a number of pathways could be involved in NIS expression. Ryan et al (20) used reverse transcription-quantitative polymerase chain reaction to measure and compare the expression levels of NIS, estrogen receptor $\alpha(E R \alpha)$ and retinoic acid receptor in healthy human breast tissue and breast cancer tissue; NIS mRNA levels were found to be closely associated with ER $\alpha$ and retinoic acid receptor expression. Cheong et al (21) further demonstrated that the ER $\alpha$ agonist $17 \beta$-estradiol could decrease ATRA-triggered iodine uptake by $50 \%$. Based on these findings, it was suggested that iodine uptake induced by ATRA was associated with ER $\alpha$-mediated transcription (21). Similarly, Lee et al (22) found that in thyroid cancer, ATRA reduced the phosphorylation levels of p38 MAPK and attenuated endoplasmic reticulum stress, subsequently affecting NIS expression and iodine uptake. Furthermore, staurosporine-associated protease inhibitors showed evident interference with ATRA-mediated iodine uptake (23). ATRA 

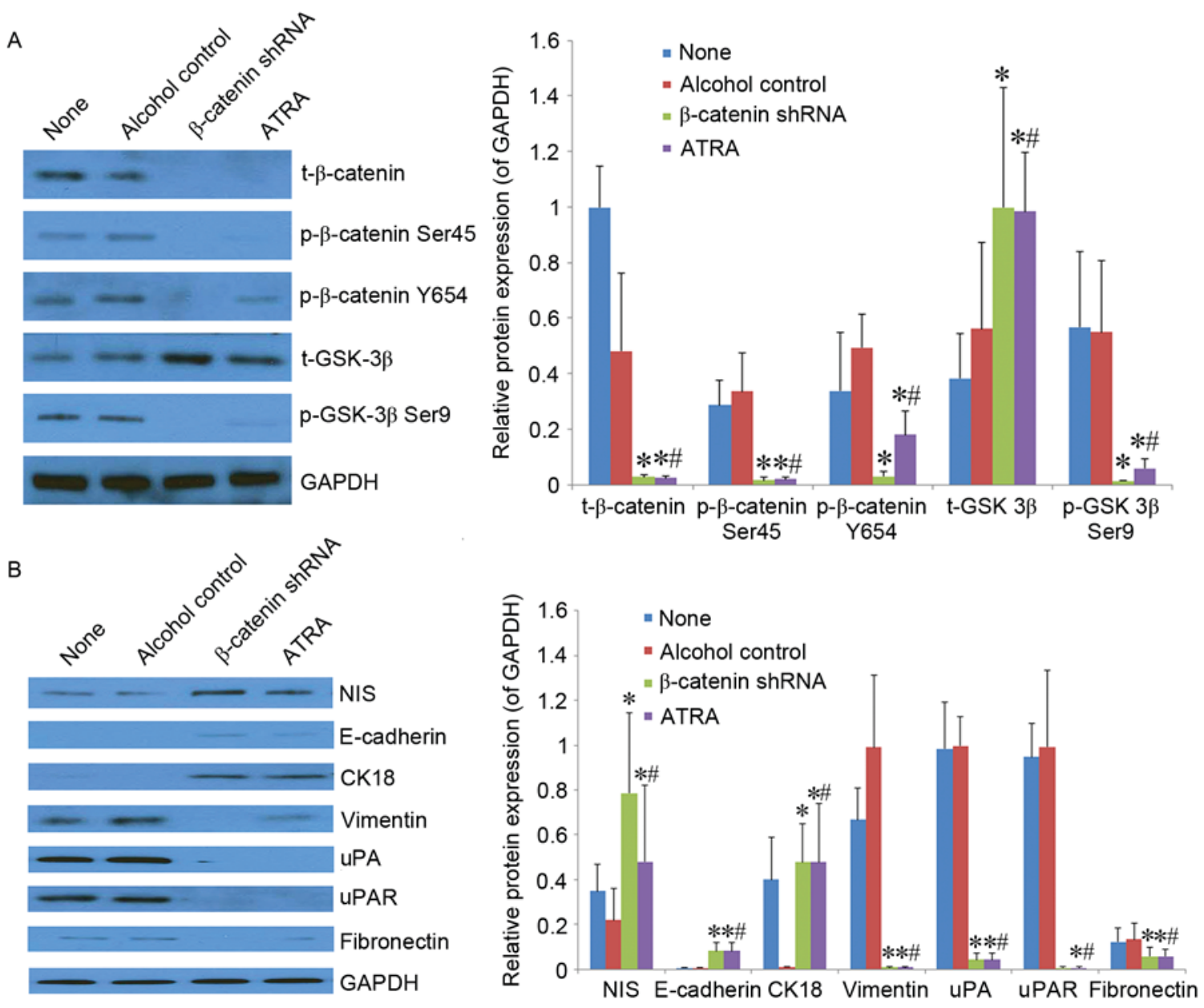

Figure 3. Effects of ATRA on the protein expression of GSK-3 $\beta, \beta$-catenin, NIS and proteins involved in epithelial-mesenchymal transition in thyroid cancer SW1736 cells. Protein expression was determined by western blot analysis. GAPDH was used as an internal control. (A) Total $\beta$-catenin, total GSK-3 $\beta$, phosphorylated $\beta$-catenin and phosphorylated GSK-3 $\beta$. (B) NIS, E-cadherin, CK18, vimentin, uPA and its receptor uPAR, and fibronectin. Data are shown as mean \pm standard deviation from three independent experiments performed in triplicate. ${ }^{*} \mathrm{P}<0.05$ vs. None; ${ }^{*} \mathrm{P}<0.05$ vs. alcohol control. None, SW1736 cells without any treatment; ATRA, all-trans-retinoic acid; shRNA, short hairpin RNA; t-, total; p-, phosphorylated; GSK-3 $\beta$, glycogen synthase kinase-3 $\beta$; CK18, cytokeratin 18; NIS, sodium/iodine symporter; uPA, urokinase-type plasminogen activator.

was reported to bind to its specific receptor and activate the PI3K/AKT signaling pathway, which may be one of the mechanisms involved in improvements of iodine uptake (24). Overall, $\beta$-catenin nuclear translocation may be one of the molecular mechanisms by which ATRA promotes iodine uptake, but additional studies remain necessary to confirm these results.

In the present study, ATRA decreased the proliferation of thyroid cancer cells, which has been previously observed in other studies of thyroid cancer cells $(9,25,26)$, as well as in other types of cancer cells, including pancreatic cancer (6), leukemia (7) and breast cancer (8). In addition, the present study showed that ATRA modulates a number of proteins involved in EMT in a way that indicates ATRA should inhibit EMT. Previous studies have shown that ATRA increases the expression of NIS, E-cadherin and CK18, and decreases the expression of vimentin, uPA, uPAR and fibronectin (27-29), as was observed in the present study. These effects should help to decrease EMT in thyroid cancers and maintain NIS potency.

Furthermore, ATRA has been shown to inhibit the proliferation and invasiveness of SW1736 cells by downregulating the transcriptional activity of $\beta$-catenin $(14,19)$. $\beta$-catenin also participates in the proliferation and invasiveness of cancer cells by modulating the $\mathrm{Wnt} / \beta$-catenin pathway. Inhibiting the Wnt/ $\beta$-catenin pathway has been shown to suppress breast cancer metastatic spread (30) and to inhibit gastric cancer stem cells (31). Therefore, the use of ATRA in thyroid cancer could affect three aspects, consisting of NIS upregulation, EMT inhibition and proliferation and invasiveness inhibition. Nevertheless, additional studies remain necessary to obtain a more comprehensive understanding of the mechanisms involved.

In conclusion, ATRA increased iodine uptake and inhibited proliferation and invasion of human anaplastic thyroid carcinoma SW1736 cells. Inhibition of $\beta$-catenin phosphorylation may be involved in this process. ATRA could be used to improve the isotope sensitivity of anaplastic thyroid carcinoma.

\section{Acknowledgements}

This study was funded by National natural science foundation (grant nos. 81372858, 30700968 and 30800416). 


\section{References}

1. Kojic KL, Kojic SL and Wiseman SM: Differentiated thyroid cancers: A comprehensive review of novel targeted therapies. Expert Rev Anticancer Ther 12: 345-357, 2012.

2. Smallridge RC, Ain KB, Asa SL, Bible KC, Brierley JD, Burman KD, Kebebew E, Lee NY, Nikiforov YE, Rosenthal MS, et al: American Thyroid Association guidelines for management of patients with anaplastic thyroid cancer. Thyroid 22: 1104-1139, 2012.

3. Glaser SM, Mandish SF, Gill BS, Balasubramani GK, Clump DA and Beriwal S: Anaplastic thyroid cancer: Prognostic factors, patterns of care, and overall survival. Head Neck 38 (Suppl 1): E2083-E2090, 2016.

4. Schenk T, Stengel S and Zelent A: Unlocking the potential of retinoic acid in anticancer therapy. Br J Cancer 111: 2039-2045, 2014.

5. Gutierrez-Mazariegos J, Schubert M and Laudet V: Evolution of retinoic acid receptors and retinoic acid signaling. Subcell Biochem 70: 55-73, 2014.

6. Leelawat K, Ohuchida K, Mizumoto K, Mahidol C and Tanaka M: All-trans retinoic acid inhibits the cell proliferation but enhances the cell invasion through up-regulation of c-met in pancreatic cancer cells. Cancer Lett 224: 303-310, 2005.

7. Liu SM, Chen W and Wang J: Distinguishing between cancer cell differentiation and resistance induced by all-trans retinoic acid using transcriptional profiles and functional pathway analysis. Sci Rep 4: 5577, 2014.

8. Tari AM, Lim SJ, Hung MC, Esteva FJ and Lopez-Berestein G: Her2/neu induces all-trans retinoic acid (ATRA) resistance in breast cancer cells. Oncogene 21: 5224-5232, 2002.

9. Zhang M, Guo R, Xu H, Zhang M and Li B: Retinoic acid and tributyrin induce in-vitro radioiodine uptake and inhibition of cell proliferation in a poorly differentiated follicular thyroid carcinoma. Nucl Med Commun 32: 605-610, 2011.

10. Muhlbauer M, da Silva AC, Marassi MP, Lourenço AL, Ferreira AC and de Carvalho DP: Retinoic acid modulation of thyroid dual oxidase activity in rats and its impact on thyroid iodine organification. J Endocrinol 205: 271-277, 2010.

11. Tang M, Hou YL, Kang QQ, Chen XY, Duan LQ, Shu J, Li SL, Hu XL and Peng ZP: All-trans-retinoic acid promotes iodine uptake via up-regulating the sodium iodide symporter in medullary thyroid cancer stem cells. Asian Pac J Cancer Prev 15: 1859-1862, 2014.

12. Dohan O, De la Vieja A, Paroder V, Riedel C, Artani M, Reed M, Ginter CS and Carrasco N: The sodium/iodide symporter (NIS): Characterization, regulation, and medical significance. Endocr Rev 24: 48-77, 2003.

13. Furuya F, Shimura H, Suzuki H, Taki K, Ohta K, Haraguchi K, Onaya T, Endo T and Kobayashi T: Histone deacetylase inhibitors restore radioiodide uptake and retention in poorly differentiated and anaplastic thyroid cancer cells by expression of the sodium/iodide symporter thyroperoxidase and thyroglobulin. Endocrinology 145: 2865-2875, 2004.

14. Sastre-Perona A and Santisteban P: Wnt-independent role of $\beta$-catenin in thyroid cell proliferation and differentiation. Mol Endocrinol 28: 681-695, 2014

15. Lan L, Deng W, Chen HL, Huo L, Deng L, Zhang G and Luo Y: Nuclear translocation of $\beta$-catenin represses membrane localization of NIS in human thyroid cancer cells. Zhonghua Yi Xue Za Zhi 96: 891-896, 2016.
16. Haberkorn U, Altmann A, Jiang S, Morr I, Mahmut M and Eisenhut M: Iodide uptake in human anaplastic thyroid carcinoma cells after transfer of the human thyroid peroxidase gene. Eur J Nucl Med 28: 633-638, 2001

17. Jiang Y,Zhao J, Wu C, Luo Y and He D: Construction and identification of shRNA eukaryotic vector targeting human $\beta$-catenin. Acad J Second Milit Med Uni 30: 965-967, 2009.

18. Nakamoto Y, Saga T, Misaki T, Kobayashi H, Sato N, Ishimori T, Kosugi S, Sakahara H and Konishi J: Establishment and characterization of a breast cancer cell line expressing $\mathrm{Na}+/ \mathrm{I}$-symporters for radioiodide concentrator gene therapy. J Nucl Med 41: 1898-1904, 2000.

19. Sastre-Perona A and Santisteban P: Role of the wnt pathway in thyroid cancer. Front Endocrinol (Lausanne) 3: 31, 2012.

20. Ryan J, Curran CE, Hennessy E, Newell J, Morris JC, Kerin MJ and Dwyer RM: The sodium iodide symporter (NIS) and potential regulators in normal, benign and malignant human breast tissue. PLoS One 6: e16023, 2011.

21. Cheong SJ, Jang D, Jeong HJ, Lim ST, Sohn MH, Katzenellenbogen JA and Kim DW: Reduction of stimulated sodium iodide symporter expression by estrogen receptor ligands in breast cancer cells. Nucl Med Biol 38: 287-294, 2011.

22. Lee SJ, Kim SH, Kang JG, Kim CS, Ihm SH, Choi MG and Yoo HJ: Effects of all-trans retinoic acid on sodium/iodide symporter and CCAAT/enhancer-binding protein-homologous protein under condition of endoplasmic reticulum stress in FRTL5 thyroid cells. Horm Metab Res 43: 331-336, 2011.

23. Beyer S, Lakshmanan A, Liu YY,Zhang X, Wapnir I, Smolenski A and Jhiang S: KT5823 differentially modulates sodium iodide symporter expression, activity, and glycosylation between thyroid and breast cancer cells. Endocrinology 152: 782-792, 2011.

24. Willhauck MJ, O Kane DJ, Wunderlich N, Göke B and Spitzweg C: Stimulation of retinoic acid-induced functional sodium iodide symporter (NIS) expression and cytotoxicity of ${ }^{131} \mathrm{I}$ by carbamazepine in breast cancer cells. Breast Cancer Res Treat 125: 377-386, 2011.

25. Kang HJ, Youn YK, Hong MK and Kim LS: Antiproliferation and redifferentiation in thyroid cancer cell lines by polyphenol phytochemicals. J Korean Med Sci 26: 893-899, 2011.

26. Malehmir M, Haghpanah V, Larijani B, Ahmadian S, Alimoghaddam K, Heshmat R, Ghavamzadeh A, Adabi K and Ghaffari SH: Multifaceted suppression of aggressive behavior of thyroid carcinoma by all-trans retinoic acid induced re-differentiation. Mol Cell Endocrinol 348: 260-269, 2012.

27. Lan L, Cui D, Luo Y, Shi BY, Deng LL, Zhang GY and Wang H: Inhibitory effects of retinoic acid on invasiveness of human thyroid carcinoma cell lines in vitro. J Endocrinol Invest 32: 731-738, 2009.

28. Dutta A, Sen T and Chatterjee A: All-trans retinoic acid (ATRA) downregulates MMP-9 by modulating its regulatory molecules. Cell Adh Migr 4: 409-418, 2010.

29. Vasko V,Espinosa AV, Scouten W, He H, Auer H,Liyanarachchi S, Larin A, Savchenko V, Francis GL, de la Chapelle A, et al: Gene expression and functional evidence of epithelial-to-mesenchymal transition in papillary thyroid carcinoma invasion. Proc Natl Acad Sci USA 104: 2803-2808, 2007.

30. Jang GB, Kim JY, Cho SD, Park KS, Jung JY, Lee HY, Hong IS and Nam JS: Blockade of Wnt/ $\beta$-catenin signaling suppresses breast cancer metastasis by inhibiting CSC-like phenotype. Sci Rep 5: 12465, 2015.

31. Mao J, Fan S, Ma W, Fan P, Wang B, Zhang J, Wang H, Tang B, Zhang Q, Yu X, et al: Roles of Wnt/ $\beta$-catenin signaling in the gastric cancer stem cells proliferation and salinomycin treatment. Cell Death Dis 5: e1039, 2014. 